\title{
The Influence of Motorcycles on Discharge Headway and Saturation Flows at Signalized Intersections under Mixed Traffic Conditions
}

\author{
I Wayan Suweda*, D. M Priyantha Wedagama \\ Department of Civil Engineering, Udayana University, Bukit Jimbaran, 80361, Bali, Indonesia
}

Received January 24, 2021; Revised March 26, 2021; Accepted April 18, 2021

\section{Cite This Paper in the following Citation Styles}

(a): [1] I Wayan Suweda, D. M Priyantha Wedagama, "The Influence of Motorcycles on Discharge Headway and Saturation Flows at Signalized Intersections under Mixed Traffic Conditions, "Civil Engineering and Architecture, Vol. 9, No. 3, pp. 595-604, 2021. DOI: 10.13189/cea.2021.090303.

(b): I Wayan Suweda, D. M Priyantha Wedagama (2021). The Influence of Motorcycles on Discharge Headway and Saturation Flows at Signalized Intersections under Mixed Traffic Conditions. Civil Engineering and Architecture, 9(3), 595-604. DOI: 10.13189/cea.2021.090303.

Copyright $\bigcirc 2021$ by authors, all rights reserved. Authors agree that this article remains permanently open access under the terms of the Creative Commons Attribution License 4.0 International License

\begin{abstract}
The high proportion of motorcycles and lack of lane discipline at signalized intersections under mixed traffic conditions are the motivation to conduct this study. The discharge headway models are constructed at three (3) signalized intersections in the SARBAGITA urban area in Bali. The result shows that motorcycles affect saturation flow due to their shorter headway than light vehicles while increasing discharge headway of other vehicles. The discharge headway between pairs of heavy vehicles is longer than these of motorcycles due to their slower acceleration at signalized intersections. This study also found that the discharge headway plays a significant role in determining the saturation flow and capacity of a signalized intersection. If a heavy vehicle is one of the pairs, then it has the potential to have a headway exceeding the other vehicle pairs. This indicates, however, that the higher proportion of motorcycles at the signalized intersection approach does not necessarily mean shorter discharge headway. There may be other influencing factors, such as the riding behavior of motorcyclists. The dominance of motorcycles can affect the value of the saturated flow, but an increase in the proportion of heavy vehicles may reduce the effect of motorcycles on the saturation flows.
\end{abstract}

Keywords Discharge Headway, Mixed Traffic, Saturation Flow, Signalized Intersection

\section{Introduction}

The discharge headway is significantly important to determine two parameters of saturation flow and time lost when the vehicle starts moving at the green time of a signalized intersection [1-4]. These two parameters are used to determine the best signal timing at a signalized intersection. Inaccuracies in the analysis of discharge headway will reduce the performance of signalized intersections. Therefore, studies related to discharge headway characteristics between queues of motor vehicles carried out at different intersections are useful to increase the estimation of saturated flow. A slight error in the estimated capacity can result in a serious problem in the estimated time delay and subsequently lead to misclassification of the operational service level of the signalized intersection [5].

The discharge headway is defined as the disparity in units of time between two consecutive motorized vehicles at a green time and crossing the signalized stop line. The differences in discharge headways may be due to the geometric factor of road intersection and traffic conditions [4-7]. Meanwhile, the method to determine the discharge headway of vehicles for homogeneous traffic conditions cannot be applied to that of heterogenous (mixed) traffic conditions with a lack of lane disciplines [2,8]. For example, two motorcycles stop parallel and are followed by a car behind it in one lane. Consequently, a formal 
definition of a gap in units of time between the front and rear vehicles does not apply in these circumstances.

A heterogeneous (mixed) traffic system is very different compared to that of a homogeneous one. For mixed traffic conditions, vehicle sizes and types and control also vary. Traffic is not segregated by vehicle type and therefore, all vehicles travel the same way. Smaller vehicles often slip through the gaps between larger vehicles and move randomly. Meanwhile, the technical guidelines for determining the road and intersection capacities in Indonesia currently refer to the Indonesian Road Capacity Manual/MKJI [9]. Due to the high proportion of motorcycles in Indonesia, including in Bali Province which exceeds $85 \%$ [10], MKJI however is considered inadequate as a reference to conduct performance analysis of roads and intersections [11]. Statistical data report that the number of motorcycles in 1997 in Bali Province was 494,057 units while in 2017 it had reached 3,337,326 units [10]. There has been an increase of almost 6.75 times the number of motorcycles for 20 years in Bali Province.

The MKJI however, is still oriented towards light vehicles as a reference for mixed traffic flow conditions that are dominated by motorcycles [11]. For this reason, the discharge headway method is expected to be used as an alternative to evaluating the performance of signalized intersections, especially for mixed traffic conditions. Previous studies have also been carried out in several developing countries which also experience mixed traffic flows $[8,12-16]$. The difference between this study and these past studies lies in the traffic characteristics. For example, in some developing countries, the mixed traffic flow consists of light and heavy vehicles, tricycles, motorcycles, and non-motorized vehicles such as cyclists and horse carriages. The traffic characteristics in Indonesia however, are dominated by motorcycles.

The lack of lane discipline of motorized vehicles within mixed traffic situations is the motivation for researching the discharge headways at signalized intersections. This study emphasizes on through movement of different types of vehicles at signalized intersections. This research was conducted at one approach of three signalized intersections in the SARBAGITA urban area in Bali. Given that in mixed traffic flows the composition of the transportation modes vary, namely motorcycles (MC), light vehicles (LV), and heavy vehicles (HV).

The specific objectives of this study are to analyze the characteristics of discharge headway of the vehicles while passing the signalized stop line and to analyze the saturated flows and passenger car equivalent (PCE) at signalized intersections under mixed traffic conditions. This study constructs discharge headways analysis as an alternative to the MKJI method for analyzing the influence of motorcycles on saturation flows at signalized intersections under mixed traffic conditions. The results of the study of discharge headway among vehicles are expected to better reflect the real condition of the signalized intersection performance under mixed traffic conditions that are dominated by motorcycles. This study contributes to formulating policies or regulations in the field of land transport, especially at signalized intersections to maximize the mobility of passenger and logistics transport. Besides, this study results may be used as input for the development of traffic simulation models and software [17], especially for mixed traffic dominated by motorcycles.

\section{Materials and Methods}

\subsection{Passenger Car Equivalent and Saturation Flows}

Methods for estimating passenger car equivalent (PCE) at signalized intersections are generally based on saturation flows. Under mixed traffic conditions, however, it is not possible to use only the queue of cars for determining the saturation flow rate (passenger car unit/hour). To convert heterogeneous traffic flows to homogeneous ones, PCE for different types of vehicles is essential. Thus, the levels of saturation flow and PCE become interdependent with one another. An alternative to PCE estimation is based on the headway method. Non-lane-based traffic under mixed traffic conditions causes one vehicle to have many other types of the vehicle next, behind, and in front of it. This makes headway measurement for PCE estimation somewhat difficult in mixed traffic conditions [18].

Meanwhile, a regression method is more relevant for PCE estimation at signalized intersections because the calculation is easier and simpler to implement. However, this method relies heavily on accurate estimation of saturation flow which is also a function of determining PCE [18]. Based on the fact that driver behavior is a major determinant of saturation flows, a well understanding of the discharge headway is essential in estimating saturation flows and saturation flow rate. A past study [19] examined the stochastic properties of the discharge headway providing better information to construct the model to estimate saturation flow rates. The discharge headway is a random variable due to differences in driver/rider behavior response times and variations in queue space length. To estimate the saturation headway, the average discharge headway is calculated as follows:

$$
\bar{h}_{s}=\frac{1}{n} \sum_{i=1}^{n} h_{s i}
$$

where,

$\bar{h}_{s}$ : the average discharge headway (s) which is taken as the estimated saturation headway $\mathrm{h}$;

$\mathrm{h}_{\mathrm{si}}$ : the discharge headway of vehicle $\mathrm{i}$ in the queue, $\mathrm{i}=$ $1,2, \ldots, \mathrm{n}$ ( $\mathrm{n}$ is the sample size), consequently, the saturation flow is conventionally determined by the discharge headway

$$
S=\frac{3600}{\bar{h}_{S}}
$$


where,

$\mathrm{S}$ is the saturation flow (vehicle/hour).

To determine the passenger car equivalent (PCE) and saturation flow, statistical criteria used are as follows (summarized in Fig.1):

1. If the discharge headway distribution is symmetrical, the average discharge headway calculated by (1) is a good (unbiased) estimate of $\mathrm{h}$, and (2) can be a good estimate for the saturation flow rate [19].

2. However, if the discharge headway distribution is not symmetrical, $h_{s}$ is not a good estimate and in (2) will give a saturation current level value that is too high (overestimate) or too low (underestimate). Therefore, it is necessary to study the stochastic nature of the time between queued vehicles and to analyze the effect of time variation between the estimated saturation flow rates [19].

3. When the average discharge headway is greater than the median value and the skewness of the discharge headway is positive, this characteristic indicates that the discharge headway distribution tends to be asymmetrical and the normal distribution function does not match the discharge headway data [19]. Therefore, the conventional method of estimating the saturation flow expressed in (2) can result in an underestimated value of the traffic flow.

4. If the discharge headway distribution tends to be asymmetrical, then the headway can be modeled with a lognormal distribution [19-20]. When the random variable $h_{s}$ function density is lognormal, $\ln h_{s}$ will follow the normal distribution. It is very relevant, therefore, to use the median value to calculate the saturation flow rate in the following way:

$$
S_{1}=3600 \times \frac{1}{h_{\text {med }}}
$$

where,

$\mathrm{S}_{1}$ : a new estimate of the saturation flow (vehicles/hour); $\mathrm{h}_{\text {med }}$ : the estimated median value of the discharge headway(sec).

5. The regression method is relevant to be used for traffic flow analysis which consists of several types of vehicles. The queue of each vehicle is calculated and regressed by the saturation flow that may occur during the analysis period. The form of the regression model is given in (4).

$$
S \text { or } S_{1}=n_{c a r}+\sum_{j=1}^{k} n_{j} . P C E_{j}
$$

where saturation flow $S$ or $S_{1}$ is obtained from either (2) or (3) depending on its types of distributions, $\mathrm{n}_{\mathrm{car}}$ and $\mathrm{n}_{\mathrm{j}}$ are the number of cars and the type of vehicle $\mathrm{j}$, respectively, crossing the stopping line during a certain period.

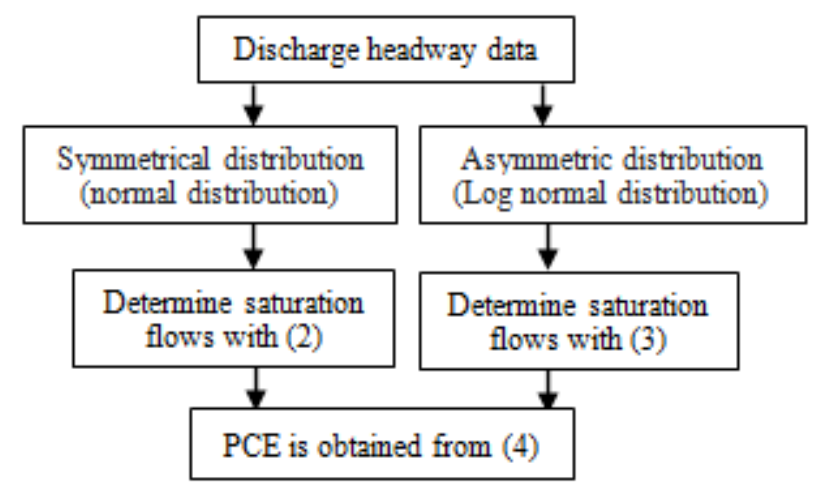

Figure 1. Determining Saturation Flows and PCE

\subsection{Data Collection}

The data collection point was carried out at one approach at three signalized intersections. These consist of the intersection of Jl. Diponegoro-Jl. Tukad Yeh Biu-Jl. P. Saelus, the intersection of Jl. Gatot Subroto - Jl. Kebo Iwa, and the intersection of Jl. Gatot Subroto - Jl. Kenyeri-Jl. Seroja. The intersection approach was chosen, among other things, which has a high traffic volume with a high proportion of motorcycles that reflect mixed traffic flow conditions. Besides, the selected intersection location has low side barriers consisting of no on-street parking, no road crossers, no non-motorized vehicles, no frontage movement along the observation segment, and no exclusive stopping space for motorcycles.

Traffic data include traffic volume and discharge headways between vehicles during the green time at one approach during morning and evening peak hours for a 1-minute interval. Traffic data are collected by marking the reference line at the intersection. The modes of transportation observed were motorcycles, light, and heavy vehicles. The geometric intersection data include side friction, lane, and road widths. Due to work safety reasons, road geometry data are collected at separate hours with low traffic conditions.

To determine the discharge headway of pairs of motor vehicles, each lane is divided into strips [4]. The width of each strip is approximately the width of the motorcycle so that the discharge headways of each pair of vehicles on each strip are measured separately and used in the analysis. Retrieval of traffic data at a signalized intersection are done by video. For volume and discharge headways, the video camera was positioned on a pole with a height of 5 meters around the intersection to provide a clear view of each vehicle. Data retrieval is carried out on one working day with morning peak hours from 07.00 to 09.00 local time and evening peak hours between 16.00 and 18.00 local time. Apart from that, the following criteria are also considered during intersection selection: 
a) The gradient for normal intersections should be as even as possible and standard lane widths should be provided.

b) Intersections must be free of bus stops, parked vehicles, pedestrians, movement, and all kinds of side obstacles.

c) The queue of through traffic should be long and consist of all types of vehicles (heavy vehicles, light vehicles, and motorcycles).

Measurement of discharge headway of vehicles when crossing stop line of the signalized intersection is carried out as follows:

a) The time of leading vehicle is the time interval between the start of green time and the rear wheel (assuming the driver is following the rear bumper of the vehicle in front) of the first vehicle in the queue passing the stop line.

b) The time of the second vehicle is the time between the rear wheel of the first and second vehicles crossing the stop line. The discharge headway for the next vehicle is measured in the same way.

c) When saturation flow is reached, only the discharge headways of the vehicles crossing the crossing stop line at the green time are considered in the analysis.

d) Discharge headway is measured for vehicles in a queued position using a stopwatch with an accuracy of 0.01 seconds.

\section{Results and Discussion}

Table 1 shows that all pairs of vehicles at all intersections have average discharge headways of less than four (4) seconds. This is in line with a past study [2] that the length of discharge headway between motorcycles and light vehicles, especially during peak morning hours is directly proportional to the length of discharge headways at signalized intersections. This is in contrast to a past study [4] that found a signalized intersection in the CBD with increasing green time, the discharge headways among motor vehicles will decrease. In other words, the length of green time is inversely proportional to the length of discharge headways at signalized intersections in urban areas [4]. In line with a past study [6], Table 1 also shows that the discharge headway has a positive influence with the increase in approach lane width.

Meanwhile, the higher the proportion of motorcycles at the approach, the shorter the discharge headway value [5]. In contrast, this study result did not show such a pattern. The proportion of motorcycles at the evening peak hours at the intersections of Jl. Diponegoro-Jl. Tukad Yeh Biu-Jl. P. Saelus and Jl. Gatot Subroto-Jl. Kebo Iwa is less than that during morning peak hours, but the discharge headways of the pair of motorcycles are longer than that in the morning. For example, the headway between pairs of motorcycles at the intersection of Jl. Diponegoro-Jl. Tukad Yeh Biu-Jl. P.
Saelus during morning peak hours has the median value of about 3.5 seconds while at the afternoon peak it is around 1 second. This suggests that under this mixed traffic condition, there may be other factors that influence the discharge headway, such as the behavior of motorcyclists at signalized intersections. In other words, the discharge headway is not influenced only by the number of motorcycles in the traffic flow but due to the lack of compliance of motorcycles with lane discipline and given the fact that motorcycles take positions in front of and between vehicles through various kinds of ways that are not uniform.

Fig. 2 shows that discharge headways between pairs of motorcycles have median values that are shorter than that of light vehicles and heavy vehicles but at the intersection of Jl. Diponegoro-Jl. Tukad Yeh Biu-Jl. P. Saelus during peak morning hours. This is similar to past research suggesting that motorcycles can affect saturation flow in two ways by having shorter discharge headways than these of light vehicles and causing longer discharge headway between other vehicles [5].

The circle or asterisk on Fig.2 shows the existence of an extreme value or outlier from time headway between pairs of motor vehicles. There are several pairs of motor vehicles at the intersection that do not have outliers. These indicate discharge headways vary but not far from the standard deviation. For example, the discharge headway between pairs of heavy vehicles at all intersections but the intersection of Jl. Gatot Subroto-Jl. Kenyeri-Jl. Seroja during afternoon peak hours. The discharge headway for pairs of heavy vehicles has a smaller variation compared to that of motorcycles. Besides, the outlier value shows that several factors can cause the discharge headway between vehicle pairs to be longer. For example, the discharge headway between pairs of motorcycles at morning peak hours at the Jl. Diponegoro-Jl. Tukad Yeh Biu-Jl. P. Saelus intersection is more than 5 seconds when the traffic volume is high.

Based on the median value in Fig.2, the discharge headway of a pair of motor vehicles is between 1 and 4 seconds. Meanwhile, the $75^{\text {th }}$ percentile values indicate that there are several vehicle pairs with discharge headway of more than 4 seconds. This shows that if a pair of motorized vehicles consisting of a heavy vehicle, it has the potential to have a discharge headway exceeding 4 seconds. It is also necessary to look at the variance in the frequency of discharge headway of motor vehicles. Fig. 2 shows that if one of the pairs consisting of a heavy vehicle (HV), it tends to have a higher frequency of discharge headway than that of light vehicles and motorcycles. This is likely due to the characteristics of heavy vehicles such as acceleration and slower moving speed at signalized intersections compared to that of light vehicles and motorcycles. This study, therefore, suggests a further study on the effect of the acceleration and speed of heavy vehicles on the saturation flows. 

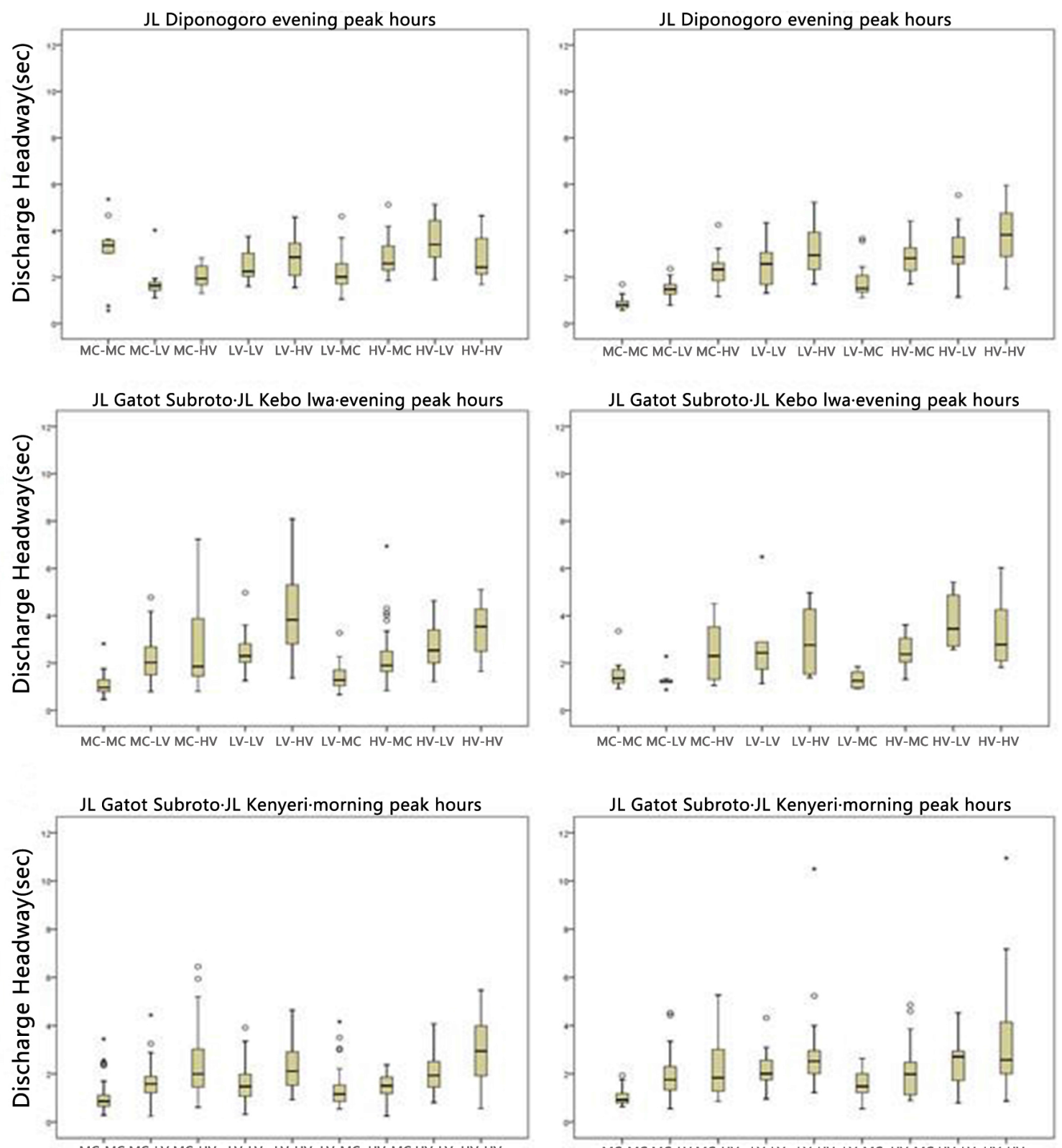

MC-MC MC-LV MC-HV LV-LV LV-HV LV-MC HV-MC HV-LV HV-HV

MC-MC MC-LV MC-HV LV-LV LV-HV LV-MC HV-MC HV-LV HV-HV

Figure 2. Vehicle Types and Discharge Headways 

at Signalized Intersections under Mixed Traffic Conditions

Table 1. Traffic and Discharge Headway Data at Morning and Evening Peak Hours

\begin{tabular}{|c|c|c|c|c|c|c|}
\hline \multirow{2}{*}{ Description } & \multicolumn{3}{|c|}{ Morning Peak Hours } & \multicolumn{3}{|c|}{ Evening Peak Hours } \\
\hline & Location 1 & Location 2 & Location 3 & Location 1 & Location 2 & Location 3 \\
\hline Approach Lane Width & $9.5 \mathrm{~m}$ & $14 \mathrm{~m}$ & $12 \mathrm{~m}$ & $9.5 \mathrm{~m}$ & $14 \mathrm{~m}$ & $12 \mathrm{~m}$ \\
\hline Green Time & $25 \mathrm{secs}$ & 32 secs & 43 secs & $55 \mathrm{secs}$ & $32 \mathrm{secs}$ & $50 \mathrm{secs}$ \\
\hline Total Traffic Volume (vehicles/hour) & 7571 & 5301 & 4431 & 3763 & 4984 & 4533 \\
\hline Light Vehicle & Location 1 & Location 2 & Location 3 & Location 1 & Location 2 & Location 3 \\
\hline $\begin{array}{c}\text { (No. of headways for LV following LV) } \\
\text { (No. of headways for LV following type } \mathrm{x} \\
\text { vehicle) } \\
\text { (No. of headways for type } \mathrm{x} \text { vehicle } \\
\text { following LV) } \\
\text { (No. of headways for type } \mathrm{x} \text { vehicle } \\
\text { following type } \mathrm{x} \text { vehicle) } \\
\text { (Mean headways for LV following LV) } \\
\text { (Mean headways for LV following type } \mathrm{x} \\
\text { vehicle) } \\
\text { (Mean headways for type } \mathrm{x} \text { vehicle following } \\
\text { LV) } \\
\text { (Mean headways for type } \mathrm{x} \text { vehicle following } \\
\text { type } \mathrm{x} \text { vehicle) }\end{array}$ & $\begin{array}{c}318 \text { cases } \\
129 \text { cases } \\
189 \text { cases } \\
1310 \text { cases } \\
2.93 \text { secs } \\
2.35 \text { secs } \\
2.08 \text { secs } \\
1.13 \text { secs }\end{array}$ & $\begin{array}{l}377 \text { cases } \\
351 \text { cases } \\
350 \text { cases } \\
1207 \text { cases } \\
2.07 \mathrm{secs} \\
1.61 \mathrm{secs} \\
1.58 \mathrm{secs} \\
1.09 \mathrm{secs}\end{array}$ & $\begin{array}{c}335 \text { cases } \\
441 \text { cases } \\
430 \text { cases } \\
1080 \text { cases } \\
2.01 \text { secs } \\
1.66 \text { secs } \\
1.56 \text { secs } \\
1.23 \text { secs }\end{array}$ & $\begin{array}{c}592 \text { cases } \\
220 \text { cases } \\
259 \text { cases } \\
2057 \text { cases } \\
2.75 \text { secs } \\
2.29 \text { secs } \\
1.92 \text { secs } \\
1.09 \text { secs }\end{array}$ & $\begin{array}{c}329 \text { cases } \\
232 \text { cases } \\
287 \text { cases } \\
1113 \text { cases } \\
2.24 \text { secs } \\
1.82 \text { secs } \\
1.65 \text { secs } \\
1.13 \text { secs }\end{array}$ & $\begin{array}{c}467 \text { cases } \\
453 \text { cases } \\
490 \text { cases } \\
1719 \text { cases } \\
2.24 \text { secs } \\
1.83 \text { secs } \\
1.82 \text { secs } \\
1.21 \text { secs }\end{array}$ \\
\hline Heavy Vehicle & Location 1 & Location 2 & Location 3 & Location 1 & Location 2 & Location 3 \\
\hline $\begin{array}{c}\text { (No. of headways for HV following HV) } \\
\text { (No. of headways for HV following type } \mathrm{x} \\
\text { vehicle) } \\
\text { (No. of headways for type } \mathrm{x} \text { vehicle } \\
\text { following HV) } \\
\text { (No. of headways for type } \mathrm{x} \text { vehicle } \\
\text { following type } \mathrm{x} \text { vehicle) } \\
\text { (Mean headways for HV following HV) } \\
\text { (Mean headways for HV following type } \mathrm{x} \\
\text { vehicle) } \\
\text { (Mean headways for type } \mathrm{x} \text { vehicle following } \\
\text { HV) } \\
\text { (Mean headways for type } \mathrm{x} \text { vehicle following } \\
\text { type } \mathrm{x} \text { vehicle) }\end{array}$ & $\begin{array}{c}59 \text { cases } \\
32 \text { cases } \\
32 \text { cases } \\
1882 \text { cases } \\
3.33 \text { secs } \\
2.63 \text { secs } \\
3.14 \text { secs } \\
1.55 \text { secs }\end{array}$ & $\begin{array}{c}35 \text { cases } \\
65 \text { cases } \\
56 \text { cases } \\
2154 \text { cases } \\
3.55 \text { secs } \\
3.15 \text { secs } \\
2.51 \text { secs } \\
1.32 \text { secs }\end{array}$ & $\begin{array}{c}39 \text { cases } \\
129 \text { cases } \\
123 \text { cases } \\
1995 \text { cases } \\
2.89 \text { secs } \\
2.42 \text { secs } \\
1.92 \text { secs } \\
1.38 \text { secs }\end{array}$ & $\begin{array}{c}36 \text { cases } \\
41 \text { cases } \\
36 \text { cases } \\
3047 \text { cases } \\
3.79 \text { secs } \\
2.63 \text { secs } \\
2.95 \text { secs } \\
1.53 \text { secs }\end{array}$ & $\begin{array}{c}34 \text { cases } \\
21 \text { cases } \\
39 \text { cases } \\
1898 \text { cases } \\
3.72 \text { secs } \\
2.85 \text { secs } \\
2.88 \text { secs } \\
1.43 \text { secs }\end{array}$ & $\begin{array}{c}35 \text { cases } \\
119 \text { cases } \\
76 \text { cases } \\
2913 \text { cases } \\
3.41 \text { secs } \\
2.44 \text { secs } \\
2.32 \text { secs } \\
1.48 \text { secs }\end{array}$ \\
\hline Motorcycle & Location 1 & Location 2 & Location 3 & Location 1 & Location 2 & Location 3 \\
\hline $\begin{array}{c}\text { (No. of headways for MC following MC) } \\
\text { (No. of headways for MC following type } \mathrm{x} \\
\text { vehicle) } \\
\text { (No. of headways for type } \mathrm{x} \text { vehicle } \\
\text { following MC) } \\
\text { (No. of headways for type } \mathrm{x} \text { vehicle } \\
\text { following type } \mathrm{x} \text { vehicle) } \\
\text { (Mean headways for MC following MC) } \\
\text { (Mean headways for MC following type } \mathrm{x} \\
\text { vehicle) } \\
\text { (Mean headways for type } \mathrm{x} \text { vehicle following } \\
\text { MC) } \\
\text { (Mean headways for type } \mathrm{x} \text { vehicle following } \\
\text { type } \mathrm{x} \text { vehicle) }\end{array}$ & $\begin{array}{c}1285 \text { cases } \\
181 \text { cases } \\
122 \text { cases } \\
358 \text { cases } \\
1.1 \mathrm{secs} \\
2.04 \mathrm{secs} \\
2.18 \mathrm{secs} \\
2.95 \mathrm{sec}\end{array}$ & $\begin{array}{c}1138 \text { cases } \\
344 \text { cases } \\
354 \text { cases } \\
449 \text { cases } \\
1 \mathrm{sec} \\
1.43 \mathrm{secs} \\
1.6 \mathrm{secs} \\
2.26 \mathrm{secs}\end{array}$ & $\begin{array}{l}931 \text { cases } \\
411 \text { cases } \\
428 \text { cases } \\
516 \text { cases } \\
1.07 \text { secs } \\
1.42 \text { secs } \\
1.67 \text { secs } \\
2.16 \text { secs }\end{array}$ & $\begin{array}{l}2019 \text { cases } \\
252 \text { cases } \\
218 \text { cases } \\
639 \text { cases } \\
1.06 \text { secs } \\
1.89 \text { secs } \\
2.22 \text { secs } \\
2.77 \text { secs }\end{array}$ & $\begin{array}{l}1079 \text { cases } \\
297 \text { cases } \\
224 \text { cases } \\
361 \text { cases } \\
1.08 \text { secs } \\
1.66 \text { secs } \\
1.74 \text { secs } \\
2.32 \text { secs }\end{array}$ & $\begin{array}{c}1625 \text { cases } \\
444 \text { cases } \\
450 \text { cases } \\
610 \text { cases } \\
1.14 \text { secs } \\
1.7 \text { secs } \\
1.79 \text { secs } \\
2.35 \text { secs }\end{array}$ \\
\hline $\begin{array}{l}\text { Note: } \\
\text { Location 1: Signalized intersection of Jl. Dip } \\
\text { Location 2: Signalized intersection of J1. Gat } \\
\text { Location 3: Signalized intersection of J1. Gat }\end{array}$ & $\begin{array}{l}\text { ro }-\mathrm{Jl} .1 \\
\text { roto }-\mathrm{Jl} \\
\text { roto }-\mathrm{Jl}\end{array}$ & Iwa & aelus & & & \\
\hline
\end{tabular}

Meanwhile, Tables 2, 3, and 4 show that the volume of motorcycles per hour at each signalized intersection is between $80 \%$ and $90 \%$ of the total motor vehicles. These summarize the estimates of saturation flows and PCE, volumes of motorcycles (MC), light vehicles (LV), heavy vehicles (HV), the average, median, and skewness of the headways. The discharge headway data for all intersections show asymmetric distribution so that the saturation flows (S1) are obtained from (3). These tables also show that PCE values obtained from the regression method vary with traffic conditions at each intersection.
Besides, these tables show that the discharge headways of motor vehicles at the three signalized intersections are not symmetrically distributed, i.e. the average value of discharge headway is higher than the median one. That indicates small discharge headways concentrated in which most drivers/riders select headways less than the average values. This may cause a high risk for the safety performance of drivers/riders at signalized intersections.

Based on Table 2, the motorcycle volumes at the signalized intersection of Jl. Diponegoro-Jl.Tukad Yeh Biu-Jl.P.Saleus in the morning peak with a range between 
2591 vehicles/hour (08.00-09.00 hours) and 2927 vehicles/hour (07.30-08.30 hours) and in the afternoon peak are between 2531 vehicles/hour (16.00-17.00 hours) and 2975 vehicles/hour (16.50-17.50 hours). Despite these maximum and minimum volumes are not exactly at the beginning and end of the morning and evening periods, Fig. 3 shows a sharp increase of saturation flows in the morning and evening peak hours by $50 \%$ and $60 \%$ respectively.

Meanwhile, Table 3 shows the motorcycle volumes at the signalized intersection of Jl.Gatot Subroto-Jl. Kebo Iwa in the morning with a range between 1521 vehicles/hour (07.00-08.00 hours) and 2382 vehicles/hour (08.00-09.00 hours) and in the afternoon are between 2154 vehicles/hour (16.20-17.20 hours) and 2260 vehicles/hour (16.40-17.40 hours). Fig.4 shows a slight increase of saturation flows in the morning and evening peak hours by $8 \%$ and $20 \%$ respectively. Table 4 also describes the motorcycle volumes at the signalized intersection of $\mathrm{Jl}$. Gatot Subroto-Jl. Kenyeri-Jl. Seroja in the morning with a range between 1898 vehicles/hour (07.00-08.00 hours) and 2758 vehicles/hour (07.50-08.50 hours) and in the afternoon peak between 3176 vehicle/hour (16.10-17.10 hours) and 3268 vehicles/hour (16.30-17.30 hours). Fig.5 shows a constant saturation flows in the morning peak period and a decrease in the afternoon peak by $20 \%$.

Table 2. PCE \& Saturation Flows at Jl. Diponegoro-Jl.Tukad Yeh Biu-Jl.P.Saleus Intersection

\begin{tabular}{|c|c|c|c|c|c|c|c|}
\hline Time & MC (veh/hr) & LV(veh/hr) & $\mathrm{HV}(\mathrm{veh} / \mathrm{hr})$ & Average (sec) & Median (sec) & Skewness (sec) & $\mathrm{S}_{1}$ \\
\hline $07.00-08.00$ & 2614 & 350 & 17 & 1.90 & 1.59 & 1.70 & 2271 \\
\hline $07.10-08.10$ & 2790 & 370 & 16 & 1.87 & 1.53 & 1.63 & 2353 \\
\hline $07.20-08.20$ & 2800 & 377 & 15 & 1.83 & 1.49 & 1.65 & 2416 \\
\hline $07.30-08.30$ & 2927 & 403 & 15 & 1.72 & 1.40 & 1.60 & 2571 \\
\hline $07.40-08.40$ & 2921 & 410 & 16 & 1.61 & 1.26 & 1.75 & 2857 \\
\hline $07.50-08.50$ & 2840 & 422 & 20 & 1.49 & 1.16 & 1.61 & 3103 \\
\hline $08.00-09.00$ & 2591 & 414 & 21 & 1.45 & 1.12 & 1.41 & 3214 \\
\hline $16.00-17.00$ & 2531 & 559 & 26 & 1.81 & 1.47 & 1.50 & 2449 \\
\hline $16.10-17.10$ & 2641 & 538 & 27 & 1.75 & 1.40 & 1.58 & 2571 \\
\hline $16.20-17.20$ & 2715 & 514 & 24 & 1.65 & 1.28 & 1.71 & 2813 \\
\hline $16.30-17.30$ & 2852 & 507 & 20 & 1.57 & 1.24 & 1.70 & 2903 \\
\hline $16.40-17.40$ & 2843 & 494 & 21 & 1.48 & 1.17 & 1.65 & 3077 \\
\hline $16.50-17.50$ & 2975 & 515 & 22 & 1.41 & 1.08 & 1.70 & 3333 \\
\hline $17.00-18.00$ & 2899 & 489 & 17 & 1.35 & 0.97 & 1.57 & 3711 \\
\hline
\end{tabular}

Table 3. PCE \& Saturation Flows at Jl.Gatot Subroto-Jl. Kebo Iwa Intersection

\begin{tabular}{|c|c|c|c|c|c|c|c|}
\hline Time & MC (veh/hr) & LV (veh/hr) & HV (veh/hr) & Average (sec) & Median (sec) & Skewness (sec) & $\mathrm{S}_{1}$ \\
\hline $07.00-08.00$ & 1521 & 368 & 21 & 1.45 & 1.18 & 2.96 & 3051 \\
\hline $07.10-08.10$ & 1753 & 421 & 22 & 1.40 & 1.16 & 3.04 & 3103 \\
\hline $07.20-08.20$ & 1898 & 460 & 21 & 1.38 & 1.15 & 3.07 & 3144 \\
\hline $07.30-08.30$ & 2085 & 496 & 18 & 1.32 & 1.15 & 2.30 & 3130 \\
\hline $07.40-08.40$ & 2202 & 533 & 17 & 1.31 & 1.13 & 2.56 & 3186 \\
\hline $07.50-08.50$ & 2308 & 524 & 29 & 1.38 & 1.13 & 31.73 & 3186 \\
\hline $08.00-09.00$ & 2382 & 525 & 33 & 1.38 & 1.50 & 0.84 & 3214 \\
\hline $16.00-17.00$ & 2166 & 545 & 44 & 1.58 & 1.34 & 2.00 & 2687 \\
\hline $16.10-17.10$ & 2245 & 536 & 43 & 1.53 & 1.29 & 2.00 & 2802 \\
\hline $16.20-17.20$ & 2154 & 502 & 33 & 1.50 & 1.26 & 1.94 & 2857 \\
\hline $16.30-17.30$ & 2245 & 481 & 29 & 1.44 & 1.23 & 1.84 & 2927 \\
\hline $16.40-17.40$ & 2260 & 469 & 30 & 1.40 & 1.18 & 1.93 & 3051 \\
\hline $16.50-17.50$ & 2248 & 450 & 30 & 1.39 & 1.15 & 1.82 & 3130 \\
\hline $17.00-18.00$ & 2221 & 448 & 25 & 1.41 & 1.18 & 1.71 & 3051 \\
\hline
\end{tabular}

Table 4. PCE \& Saturation Flows at Jl. Gatot Subroto-Jl. Kenyeri-J1. Seroja Intersection

\begin{tabular}{|c|c|c|c|c|c|c|c|}
\hline Time & $\mathrm{MC}$ (veh/hr) & LV (veh/hr) & HV(veh/hr) & Average (sec) & Median (sec) & Skewness (sec) & $\mathrm{S}_{1}$ \\
\hline $07.00-08.00$ & 1898 & 426 & 78 & 1.35 & 1.15 & 1.92 & 3130 \\
\hline $07.10-08.10$ & 2063 & 437 & 73 & 1.35 & 1.16 & 1.88 & 3103 \\
\hline $07.20-08.20$ & 2274 & 499 & 82 & 1.35 & 1.15 & 1.88 & 3130 \\
\hline $07.30-08.30$ & 2454 & 515 & 99 & 1.35 & 1.11 & 2.11 & 3243 \\
\hline $07.40-08.40$ & 2656 & 529 & 113 & 1.38 & 1.18 & 1.81 & 3051 \\
\hline $07.50-08.50$ & 2758 & 544 & 122 & 1.49 & 1.27 & 28.90 & 2846 \\
\hline $08.00-09.00$ & 2686 & 562 & 124 & 1.58 & 1.15 & 29.03 & 3130 \\
\hline $16.00-17.00$ & 3192 & 676 & 99 & 1.49 & 1.26 & 3.06 & 2857 \\
\hline $16.10-17.10$ & 3176 & 617 & 103 & 1.50 & 1.26 & 3.00 & 2857 \\
\hline $16.20-17.20$ & 3201 & 633 & 114 & 1.60 & 1.39 & 2.53 & 2590 \\
\hline $16.30-17.30$ & 3268 & 638 & 107 & 1.59 & 1.38 & 2.14 & 2609 \\
\hline $16.40-17.40$ & 3328 & 642 & 103 & 1.60 & 1.38 & 2.05 & 2618 \\
\hline $16.50-17.50$ & 3264 & 641 & 90 & 1.61 & 1.40 & 2.00 & 2571 \\
\hline $17.00-18.00$ & 3214 & 604 & 85 & 1.62 & 1.43 & 1.52 & 2517 \\
\hline \multicolumn{8}{|c|}{$\mathrm{R}^{2}=89.00 \% ;$ Adjust $\mathrm{R}^{2}=87.00 \%$; pce $(\mathrm{mc})=1.02 ;$ pce $(\mathrm{hv})=0.23 ;$ pce $(\mathrm{lv})=1.00$} \\
\hline
\end{tabular}


The differences in the pattern of saturation flow at each intersection are likely due to the proportion of heavy vehicles. The lowest proportion of heavy vehicles is at Jl. Diponegoro-Jl. Tukad Yeh Biu-Jl. P. Saleus Intersection, while the largest one is at Jl. Gatot Subroto-Jl. Kenyeri-Jl. Seroja Intersection. In other words, if the proportion of motorcycles dominates, then it will influence the saturation flow of the intersection. However, the addition of the proportion of heavy vehicles can reduce the effect of motorcycles on the saturated flows. Also, the differences in saturation flow per segment of time during morning and evening peak hours on each signalized intersection can be attributed to the driver/rider behavior.

Meanwhile, considering Table 1 and Figures 3, 4, and 5, there are significant increases in saturation flows with increases in approach lane width. This is evidence that the discharge headway varies at each intersection depending on intersection geometry. The wider the approach width, the higher number of vehicles passing through the intersection, hence the higher will be the saturation flows. Also, a better traffic control system is required to improve service and anticipate congestion at the intersection [21], for instance, a traffic-responsive control method at signalized intersections. The controller can deal with a time-varying parameter, namely the saturation flow rate of the intersection. This benefits to mitigate the number of vehicles waiting at the stop line.

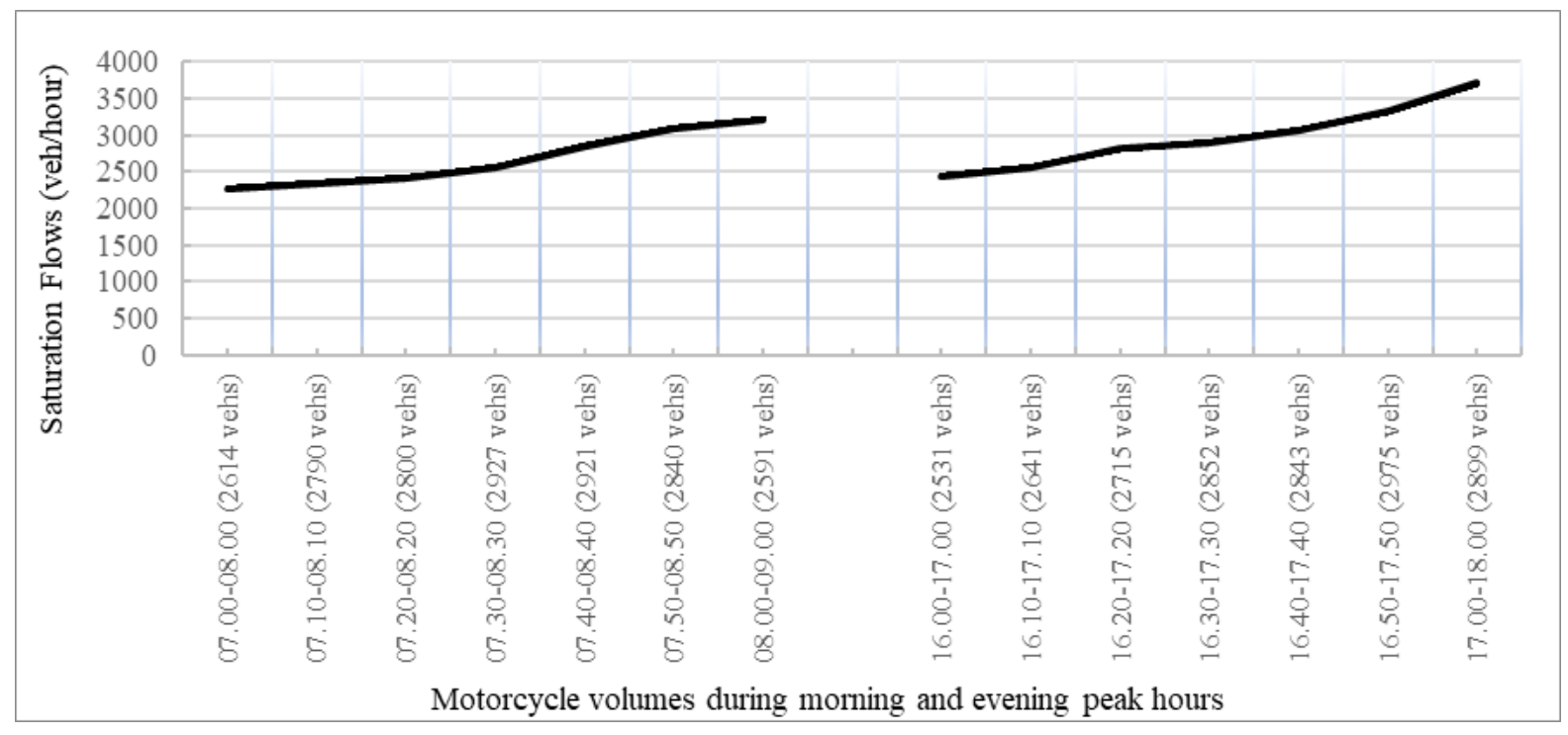

Figure 3. Motorcycles \& Saturation Flows at Jl. Diponegoro-Jl. Tukad Yeh Biu-Jl. P. Saleus Intersection

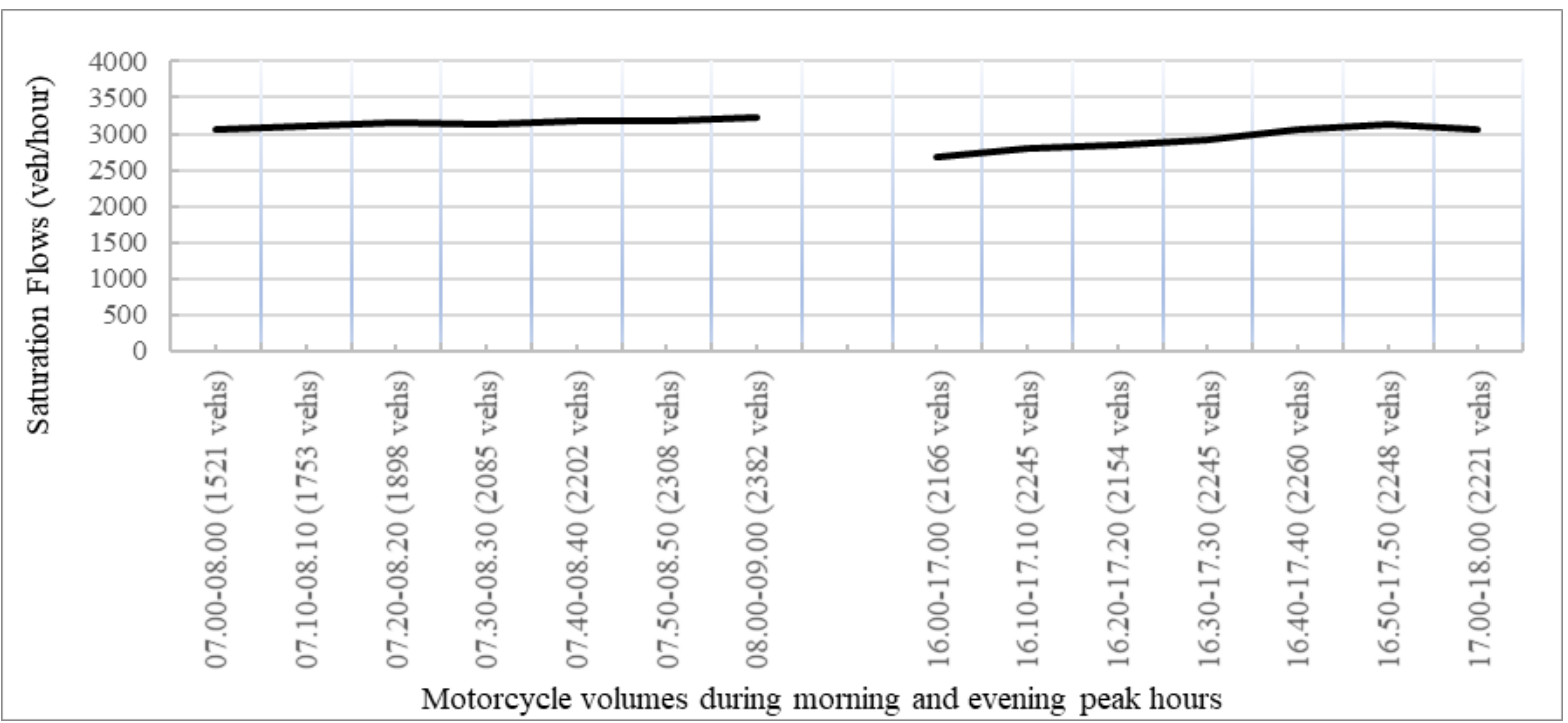

Figure 4. Motorcycles \& Saturation Flows at Jl. Gatot Subroto-Jl. Kebo Iwa Intersection 


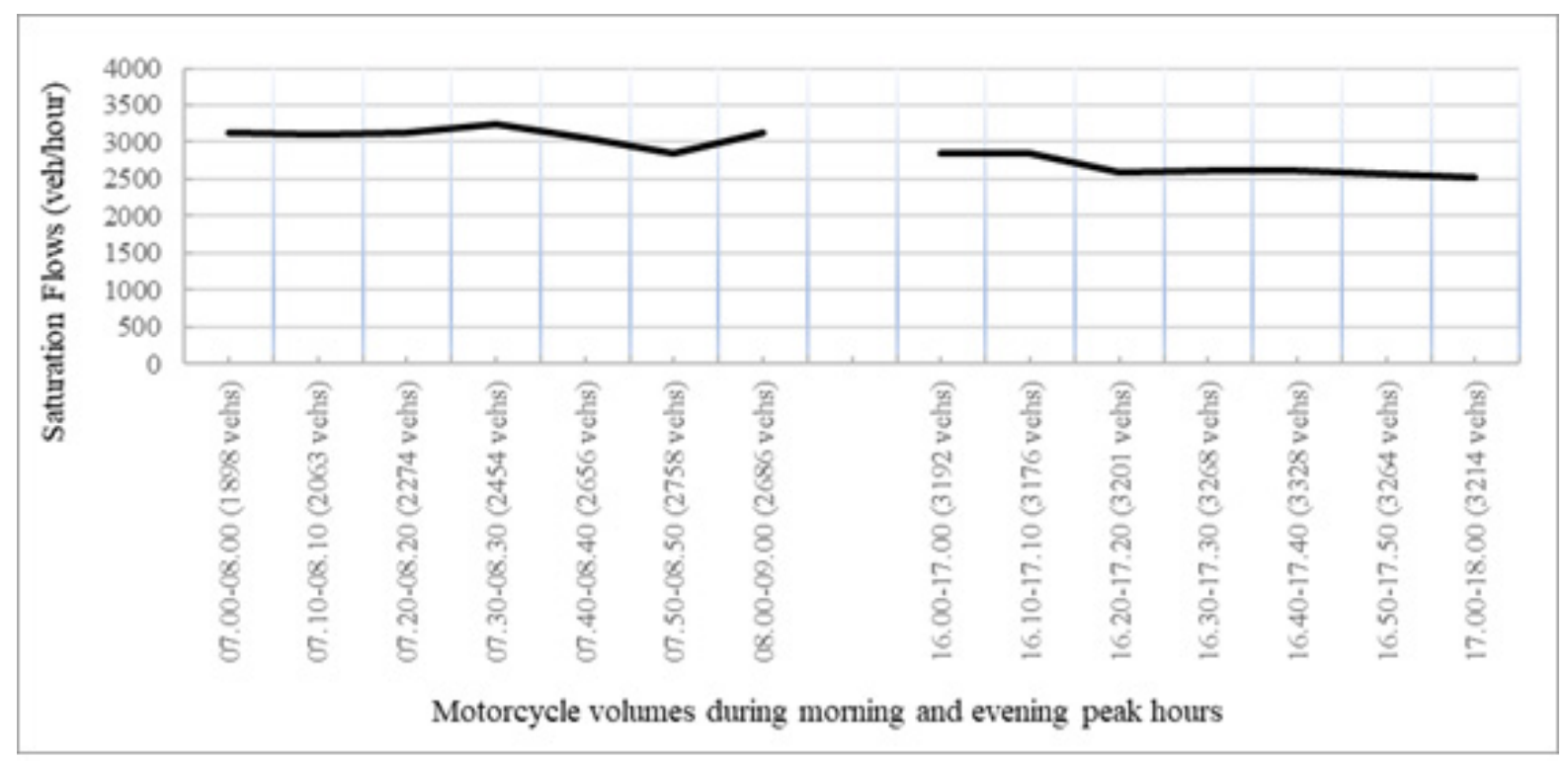

Figure 5. Motorcycles \& Saturation Flows at Jl. Gatot Subroto-Jl. Kenyeri-Jl. Seroja Intersection

\section{Conclusions}

This study aims to construct discharge headway models to examine the effect of motorcycles on saturation flows using three signalized intersections under mixed traffic conditions in Bali as the case study. This study found that the discharge headways vary at each signalized intersection depending on factors such as traffic composition/traffic characteristics and approach lane width/intersection geometry

The higher proportion of motorcycles, however, does not necessarily mean the lower values of the discharge headway at a signalized intersection approach. There may be other factors that influence the value of the discharge headway between vehicles, for example, the behavior of motorcyclists at signalized intersections. This study discovered that the discharge headways between vehicles were affected not only by the number of motorcycles in the traffic flow but also by the lack of motorcycle compliance with lane discipline and given the fact that motorcycles take positions in front of and between vehicles in a variety of non-uniform ways. Further research, therefore, is required to analyze the driver/rider behaviors and discharge headways at signalized intersections

Motorcycles can affect saturation flows in two ways namely their use time is shorter than that of light and heavy vehicles, while at the same time motorcycles may increase the time headway between other types of vehicles. The discharge headway for pairs of heavy vehicles has a smaller variation than pairs of motorcycles. If one of the pairs consisting of a heavy vehicle then it has the potential to have a discharge headway exceeding the other vehicle pairs. Also, if one of the motorized vehicles consisting of a heavy vehicle (HV), it tends to have a higher frequency of discharge headway than that of light vehicles and motorcycles. This is likely due to the characteristics of heavy vehicles such as acceleration and slower moving speed at signalized intersections when compared to light vehicles and motorcycles. A further study, therefore, is needed to establish the relationship between acceleration and speed characteristics of heavy vehicles and the saturation flows at signalized intersections.

The wider the approach width, the higher number of vehicles passing through the intersection, hence the higher will be the saturation flows. Also, the variation of PCE values and saturation flow at each intersection support the assumption that these signalized intersections are under mixed traffic conditions

\section{Acknowledgments}

This work was supported by the University of Udayana, Bali, Indonesia

\section{REFERENCES}

[1] R. AkÇelik, M. Besley. Queue Discharge Flow and Speed Models for Signalised Intersections, Paper presented at the $15^{\text {th }}$ International Symposium on Transportation and Traffic Theory, Adelaide, Australia, 2002.

[2] S. Radhakrishnan, G. Ramadurai. Discharge headway model for heterogeneous traffic conditions, Transportation Research Procedia, Vol.10, 145 - 154, 2015.

[3] J. Zhao, P. Li, X. Zhou. Capacity estimation model for signalized intersections under the impact of access point, PLoS ONE, Vol.11, No.1, e0145989, 1-16, 2016.

[4] M. Rameez, S. Singla, M. Kaushal. A study on discharge headway modeling at a signalized intersection under 
heterogeneous traffic conditions, International Journal for Research in Applied Science \& Engineering Technology, Vol.6, No.X, 232-238, 2018

[5] C.A. Adams, M.A.M. Zambang, R. Opoku - Boahen. Effects of motorcycles on saturation flow rates of mixed traffic at signalized intersections in Ghana, International Journal of Traffic and Transportation Engineering, Vol. 4, No.3, 94-101, 2015.

[6] P.N.Patel, A. Dhamaniya, B.K. Katti. Effect of mixed traffic characteristics on saturation flow and passenger car units at signalised intersections, European Transport, Issue 59, Paper No. 4, 1-16, 2015.

[7] P.V. Suvin, C. Mallikarjuna. Modified generalized definitions for the traffic flow characteristics under heterogeneous, no-lane disciplined traffic streams, Transportation Research Procedia, Vol. 34, 75-82, 2018.

[8] K. Bhattacharyya, B. Paul, B. Maitra. Dynamics of vehicle discharge at signalized intersections with non-lane based mixed traffic operations, Asian Transport Studies, Vol. 5, No. 2, 310-325, 2018.

[9] Directorate General of Highways. Indonesian Road Capacity Manual, Ministry of Public Works, Jakarta, 1997.

[10] Central Bureau of Statistics of Bali Province. Bali in Figures, Bali Provincial Government, Denpasar, 2018.

[11] Munawar, A., Irawan, M.Z., Fitrada, A.G., 2018. Developing Indonesian Highway Capacity Manual Based on Microsimulation Model (A Case of Urban Roads). In: Proceeding Transactions on Engineering Technologies: 25th World Congress on Engineering, pp.153- 163.

[12] I. Bargegol, A.T. Amlashi, V.N.M. Gilani. Evaluation average discharge headway at nearside legs of signalized intersections, Journal UMP Social Sciences and Technology Management, Vol.3, No.3(1), 670-675, 2015.
[13] S.P. Çalişkanelli, S. Tanyel. Investigating the driver's response time at signalized intersections, Transport, Vol.33, No. 2, 380-388, 2018

[14] S.P. Calıșkanelli, F.C. Atasever, S. Tanyel. Start-up lost time and its effect on signalized intersections in Turkey, Traffc \& Transportation, Vol.29, No. 3, 321-329, 2017.

[15] T.B. Rajgor, A.K. Patel, P.J. Gundaliya. Development of saturation flow rate model for heterogeneous traffic at urban signalized intersection, International Journal of Innovative Research in Technology, Vol.2, No.12, 151-155, 2016.

[16] A. Sharma, L. Vanajakshi, N. Rao. Effect of phase countdown timers on queue discharge characteristics under heterogeneous traffic condition, Transportation Research Record: Journal of the Transportation Research Board, No. 2130, 93-100, 2009

[17] M.Alkubaisi. Development of freeway weaving areas microsimulation model (FWASIM), Civil Engineering and Architecture, Vol. 8, No. 5, 1006 - 1018, 2020.

[18] M. Mohan, S. Chandra. Queue clearance rate method for estimating passenger car equivalents at signalized intersections, Journal of Traffic and Transportation Engineering, Vol.4, No.5, 487-495, 2017.

[19]C. Shao, X. Liu. Estimation of saturation flow rates at signalized intersections, Discrete Dynamics in Nature and Society, Vol. 2012, Article ID 720474, 9 pages, 2012.

[20] M.S. Chaudhry, P. Ranjitkar, D.J. Wilson. Queue discharge behavior at signalized intersection: a comparison between field measurements with analytical and microsimulation models, Journal of the Eastern Asia Society for Transportation Studies, Vol.9, 1628-1643, 2011.

[21]A. Setiawan. Evaluation of performance non-signal intersection on telekomunikasi road intersection - Terusan Buah Batu Road, Bandung - West Java, Civil Engineering and Architecture, Vol.7, No. 3A, 77-85, 2019. 